\title{
EFEK PEMBERIAN SUPLEMEN SINBIOTIK DAN ZAT GIZI MIKRO (VITAMIN A DAN ZINC) TERHADAP STATUS GIZI PENDERITA TBC PARU ORANG DEWASA YANG MENGALAMI KEKURANGAN ENERGI KRONIK
}

\author{
Suparman'; Hardinsyah2; Clara M Kusharto²; Ahmad Sulaeman2; dan Bachti Alisjahbana ${ }^{3}$ \\ ${ }^{1}$ Mahasiswa Program Doktor, Sekolah Pascasarjana IPB \\ 2Departemen Gizi Masyarakat, Fakultas Ekologi Manusia, IPB \\ ${ }^{3}$ Fakultas Kedokteran, Universitas Padjadjaran
}

\begin{abstract}
ABSTRAK
Pasien TB paru pada akhirnya akan mengalami keadaan gizi buruk dan menurunnya respon imun. Kemoterapi dengan menggunakan obat-obatan TB merupakan langkah yang efektif untuk mengobati penyakit ini, tetapi mempunyai pengaruh negatif terhadap keseimbangan mikropola usus inflamasi karena infeksi TB paru, menurunkan pengaturan sintesa zat gizi dan menurunkan nafsu makan, sehingga terjadi kekurangan gizi. Penelitian bertujuan untuk menganalisa efikasi symbiotik dan suplemen zat gizi mikro terhadap status gizi pada pasien dewasa TB paru yang sedang diobati yang menderita kekurangan energi kronik setelah 2 bulan menjalani intervensi. Desain penelitian "a double-blind randomized treatment control trial" dilakukan pada 2 pusat penyembuhan TB paru di Bandung dan Garut. Sejumlah 43 orang yang menderita kekurangan energi kronik (KEK) dipilih dari 76 pasien TB paru yang terekrut dengan variasi umur antara 20-45 tahun. Kelompok ini dibagi 2 kelompok, kelompok pertama diberikan susu yang berisi protein, symbiotik dan suplemen micronutrien (MSM) dan kelompok kedua diberi susu yang berbasis protein saja (MO) sebagai kelompok kontrol. Seluruh pasien menerima terapi standar untuk TB paru, parameter status gizi (BB, IMT, masa Lemak, hemoglobin, serum vitamin A dan seng) dikumpulkan pada saat awal setelah 1 bulan, 2 bulan dari pemberian intervensi data di awalnya. Perbedaan antara dan dalam kelompok menggunakan statistik parametrik dan non parametric. Hasil menunjukan bahwa setiap kelompok pada akhir intervensi parameter status gizi secara signifikan mengalami perbaikan dibandingkan pada awal penelitian $(P<0,05)$ tetapi tidak ada perbedaan signifikan antara dua kelompok $(p>0,05)$. Ada pengaruh potensial dari setiap suplemen dalam meningkatkan status gizi, penelitian yang lebih lama dengan tidak memberikan susu berbasis protein pada kelompok kontrol dibutuhkan.
\end{abstract}

Kata kunci: imunitas, zat gizi mikro, symbiotik, TB paru

\section{ABSTRACT}

THE EFFECT OF SYNBIOTIC AND MICRONUTRIENT SUPPLEMENTS ON IMPROVING NUTRITIONAL STATUS AMONG TREATED ADULT PULMONARY TUBERCULOSIS PATIENTS WHO SUFFERED CHRONIC ENERGY DEFICIENCY (CED)

Pulmonary tuberculosis patients are eventually poor nutritional status and lacking immune response. Chemotherapy using multi-drugs-TB is effective way to treat the disease, however probably there is negative effect on imbalance gut microflora. Inflammation due to pulmonary tuberculosis infection downregulated nutrients synthesis and lowering appetite, therefore nutrient deficiency occurred. The study objective is to analyze the efficacy of synbiotic and micro-nutrients supplements on nutritional status among treated adult pulmonary tuberculosis (TB) patients who suffered chronic energy deficiency after 2 months intervention. This study is a double-blind randomized treatment-control trial design conducted at two community TB Centers in Bandung and Garut. Forty three subjects aged 20-45 years suffered CED were selected from recruited 76 new cases of pulmonary TB patients. They were divided into two groups; the first group treated with milk based protein, synbiotic and micronutrients supplements (MSM); and the second group treated with milk based protein only (MO) as a control group. All patients received a standard TB therapy. Parameters of nutritional status (body weight, BMI, fat mass, hemoglobin, serum vitamin. A and serum zinc) were collected at baseline, after 1,2 months of intervention. Data were analyzed to assess the difference between and within group using parametric and non parametric statistic. The results showed that in each group at the end line nutritional status parameters were significantly better than the baseline nutritional status parameters $(p<0.05)$, but not significantly difference between the two groups $(p>0,05)$. In conclusion, there was potential effect of the each supplement to improved nutritional status. It is suggested that a longer study with no milk based protein control group is required.

Keywords: micronutrients, immunity, synbiotic, tuberculosis 


\section{PENDAHULUAN}

D iperkirakan antara 19 sampai 43 persen populasi dunia terinfeksi oleh mycobacterium tuberculosis.

Tuberkulosis (TBC) adalah penyakit sosial dengan implikasi medis. Penyakit ini sering terjadi pada populasi yang kurang beruntung seperti: miskin, tidak memiliki tempat tinggal, kekurangan gizi, buruknya sanitasi dan kepadatan penduduk1.

Berdasarkan data Surkesnas (Survei Kesehatan Nasional) tahun 2004, prevalensi penyakit TBC paru berdasarkan pemeriksaan smear sputum pada populasi usia lebih dari 15 tahun adalah 240 per 100.000 penduduk pada tahun 20042. Pada umumnya penderita TBC paru pada kelompok usia produktif di Indonesia dan Singapura, menderita kekurangan energi kronis $^{3,4}$, defisiensi zinc dan retinol plasma ${ }^{5}$.

Penderita TBC paru umumnya mengalami penurunan berat badan akibat asupan makanan rendah yang dipicu oleh selera makan menurun. Sitokin-sitokin proinflammatory yang disekresi sel-sel imun sebagai respon imunitas terhadap infeksi bakteri TBC, diduga menjadi penyebab perubahan metabolisme yang sering menimbulkan terjadinya kekurangan energi kronis ${ }^{6}$. Produksi IFN- $\gamma$ dan TNF- $\alpha$ merupakan respon pertahanan tubuh melawan tuberkulosis, tetapi hal ini juga selalu berkaitan dengan munculnya anoreksia dan demam ${ }^{7}$. Suatu studi di Amerika pada sejumlah pasien yang didiagnosa menderita tuberkulosis, menunjukkan 45 persen mengalami kehilangan berat badan dan 26 persen anoreksia 8 . Kekurangan energi-protein, berkaitan dengan menurunnya imunitas tubuh (immune suppression) terutama fungsi sel $\mathrm{T}^{9}$.

Pengobatan kemoterapi menggunakan obat anti tuberkulosis (OAT), mampu menurunkan peradangan dan kenaikan berat badan ${ }^{10}$. Kombinasi pengobatan kemoterapi dan pemberian makanan tambahan dapat meningkatkan respon imun dan lebih cepat menghasilkan clearence sputum serta meningkatkan keseluruhan angka kesembuhan (cure rate $)^{4}$. Intervensi dengan pemberian suplemen energi dan protein, walaupun mampu meningkatkan berat badan, tetapi hanya meningkatkan masa lemak tidak masa protein ${ }^{11}$. Demikian juga intervensi lain dengan menambahkan vitamin $A$ dan zinc pada pengobatan standar TBC paru mampu meningkatkan perbaikan klinis dan kenaikan kadar vitamin A dan zinc plasma ${ }^{5}$.

Pemberian obat anti tuberkulosis (multidrugs TB) untuk mengobati penyakit TBC paru yang terdiri atas beberapa antibiotika, diduga akan memberikan pengaruh buruk terhadap mikroflora di saluran pencernaan ${ }^{12,13}$. Pemberian antibiotik spektrum luas menimbulkan sejumlah efek merugikan dalam hubungannya dengan keseimbangan microflora usus, karena menimbulkan perubahan komposisi microflora usus ${ }^{14}$.

Penggunaan probiotik dan prebiotik dapat memelihara keseimbangan mikroflora usus karena mikroba eksogen memunculkan efek fisiologik menguntungkan bagi mikroflora normal usus $^{15}$ dan prebiotik menyediakan makanan bagi bakteri probiotik indigenus ${ }^{16}$. Tujuan penelitian ini untuk menganalisis pengaruh suplemen berbahan susu, sinbiotik dan zat gizi mikro terhadap status gizi penderita TBC paru orang dewasa yang mengalami kekurangan energi dan protein setelah 2 bulan intervensi.

\section{METODE PENELITIAN}

Bahan suplemen terdiri dari (a) suplemen susu (300 kkal, 13,9 gram protein) dikemas alumunium foil, (b) kapsul sinbiotik $\left(5 \times 10^{9} \mathrm{cfu}\right.$ Lactobacillus acidophilus dan Bifidobacterium longum dan 15 persen atau $60 \mathrm{mg}$ Fructooligosacharides) dikemas botol plastik putih tidak tembus cahaya, (c) kapsul zat gizi mikro (5000 IU vitamin A dan $15 \mathrm{mg}$ zinc) dikemas botol plastik putih tidak tembus cahaya dan (4) standar pengobatan anti tuberculosis FDC (fixed drugs combination) yang diberikann fase awal - dua bulan pertama (intensive phase): $150 \mathrm{mg}$ Rifampisin, $75 \mathrm{mg}$ Isoniazid, $400 \mathrm{mg}$ Pirazinamid dan $275 \mathrm{mg}$ Etambuthol dan fase lanjutan selama 4 bulan (follow-up phase): $150 \mathrm{mg}$ Rifampisin dan $150 \mathrm{mg}$ Isoniazid.

Spesimen dahak dikumpulkan dengan 3 buah kontainer plastik, sedangkan darah vena untuk penenentuan kadar hemoglobin, vitamin A serum dan zinc serum diambil dari setiap subjek masing-masing dimasukkan kedalam tabung EDTA $3 \mathrm{~mL}$ dan kedalam tabung plain 2 $\mathrm{mL}$ menggunakan syringe venoject. 
Pengumpulan specimen feses menggunakan botol plastik bertutup dan setelah pengenceran $10^{-1}$ menggunakan $\mathrm{NaCl} 0,85$ persen steril, feses disimpan kedalam kantong plastik dan media agar dalam lemari es. Bahan untuk kultur kedua bakteri probiotik adalah media MRS agar (kultur untuk Lactobacillus sp) dan media TPY (kultur untuk Bifidobacterium $s p)$.

Pengukuran berat badan, lemak tubuh dan air tubuh menggunakan timbangan digital SECA tipe 804 dengan ketelitian $0,1 \mathrm{~kg}$ dan alat ukur tinggi badan dengan alat ukur tinggi badan ketelitian $0,1 \mathrm{~cm}$ (bahan fiberglas, Puslitbang Gizi \& Makanan).

Penelitian ini menggunakan disain experimental teracak buta ganda (a doubleblind randomized treatment-control trial). Subjek dibagi ke dalam dua kelompok secara acak. Satu kelompok diberi 2 kapsul sinbiotik dan 1 kapsul zat gizi mikro Setiap hari, selanjutnya disebut kelompok MSM (menerima suplemen susu, sinbiotik \& zat gizi mikro). Kelompok kedua tidak diberi supplemen (hanya menerima suplemen susu) adalah kelompok kontrol, selanjutnya disebut kelompok MO. Suplemen kelompok MSM dan MO diberikan selama 56 hari berturut-turut (sesuai fase intensif pengobatan TB).

Dalam upaya meminimalisasi interaksi antara obat anti TB, sinbiotik dan zat gizi mikro, dilakukan pemisahan jadwal minum ketiga bahan dengan perbedaan waktu minum minimal 4 jam. Waktu penelitian selama 12 bulan dimulai bulan November 2009. Tempat penelitian di 2 tempat yaitu Balai Besar Kesehatan Paru Masyarakat (BBKPM) Bandung dan Balai Kesehatan Paru Masyarakat (BKPM) Garut.

Populasi target penelitian adalah seluruh penderita TBC paru baru berusia 20-45 tahun yang datang memeriksakan diri ke BBKPM Bandung dan BKPM Garut selama bulan November 2009 - Agustus 2010. Sampel penelitian ini adalah populasi target yang memenuhi kriteria inklusi yaitu baru terdeteksi BTA positif baru, berumur 20-45 tahun, sedangkan kriteria eksklusi yaitu tidak menderita DM (diabetes mellitus) dan gangguan fungsi ginjal, tidak hamil dan menyusui. Selanjutnya sampel mendapatkan penjelasan penelitian dan diminta kesediaan menandatangani formulir persetujuan (informed consent) sampel dipilih dan ditempatkan kedalam kelompok MSM dan kontrol secara acak. Persetujuan etik penelitian ini diperoleh dari Badan Penelitian dan Pengembangan Kesehatan, Kementerian Kesehatan RI.

Jumlah minimal sampel penelitian dihitung menggunakan rumus minimum sample size for estimating difference mean between groups (17) dengan asumsi $\alpha=5 \%(Z \alpha=1,96)$; power of test $=80 \%(Z \beta=0,84), X 1=48,0 \%$ (persen neuthrophil awal ) dan $X 2=55,3 \%$ (persen neutrophil akhir) dari penelitian preliminary. Hasil perhitungan diperoleh jumlah sampel minimal (n) sebanyak 38 sampel untuk setiap kelompok atau seluruhnya menjadi 76 sampel. Dari hasil analisis diperoleh prevalensi kekurangan energi kronis (KEK) sebanyak 56,6 persen, sehingga jumlah subjek yang dikaji yaitu penderita TBC paru yang mengalami KEK sebanyak 43 orang.

Jenis data dikumpulkan meliputi: data umum dan sosial-ekonomi, data pemeriksaan klinis (tanda/gejala, skor karnofsky, suhu tubuh), data pemeriksaan laboratorium (sputum, darah dan feses) data antropometri (berat, tinggi badan). Status gizi dinilai berdasarkan IMT, kadar hemoglobin, serum retinol dan serum zinc.

Analisis populasi bakteri probiotik Lactobacillus $s p$ dan Bifidobacterium $s p$ dilakukan secara manual dengan menghitung jumlah koloni setelah dilakukan kultur menggunakan media MRS dan TPY. Analisis hemoglobin menggunakan alat sysmex, kadar vitamin A serum ditentukan menggunakan HPLC (High Performance Liquid Chromatography), sedangkan kadar zinc serum mennggunakan AAS (Atomic Absorbance Spectrophotometer). Analsisi data untuk menjawab tujuan penelitian menggunakan uji parametrik dan non paramerik, terutama uji beda independen dan berpasangan.

\section{HASIL DAN BAHASAN}

\section{Karakteristik Sampel}

Hasil uji beda karakteristik sampel pada Tabel 1, di antara kedua kelompok (MSM dan MO), yaitu meliputi: usia, jenis kelamin, tingkat pendidikan, pendapatan, jumlah anggota keluarga, suku, status gizi, status anemia dan smear sputum menunjukkan hasil tidak berbeda 
nyata $(p>0,05)$. Subjek merupakan penderita TBC paru baru dan tidak ada perbedaan kategori smear sputum di antara kedua kelompok $(p>0,05)$.

Tabel 1

Sebaran Subjek Menurut Karasteristik awal

\begin{tabular}{|c|c|c|c|}
\hline Karakteristik & Kelompok MSM & \multicolumn{2}{|l|}{ Kelompok MO } \\
\hline Jumlah subjek (n) & 21 & \multicolumn{2}{|l|}{22} \\
\hline Usia (mean $\pm S D$, tahun) ${ }^{1}$ & $29,3( \pm 7,4)$ & \multicolumn{2}{|l|}{$30,3( \pm 7,3)$} \\
\hline \multicolumn{4}{|l|}{ Janis kelamin $(\%)^{2}$} \\
\hline Laki-laki & 44,0 & 56,0 & 100,0 \\
\hline Perempuan & 51,9 & 48,1 & 100,0 \\
\hline \multicolumn{4}{|l|}{ Pendidikan (\%) ${ }^{2}$} \\
\hline SD & 40,0 & 54,5 & \\
\hline SMP & 20,0 & 27,3 & \\
\hline \multirow[t]{2}{*}{ SMA } & 40,0 & 18,2 & \\
\hline & 100,0 & 100,0 & \\
\hline Pendapatan (kapita/bulan,SD) 1 & Rp. 223.294ะ Rp. 171.974 & \multicolumn{2}{|c|}{$\operatorname{Rp} 235.222 \pm \operatorname{Rp} 161.858$} \\
\hline \multicolumn{4}{|l|}{ Suku $(\%)^{2}$} \\
\hline Sunda & 95,0 & 100,0 & \\
\hline \multirow[t]{2}{*}{ Jawa } & 5,0 & 0,0 & \\
\hline & 100,0 & 100,0 & \\
\hline \multicolumn{4}{|l|}{ Status gizi } \\
\hline Berat badan $(\mathrm{kg} \pm \mathrm{SD}){ }^{1}$ & $41,7 \pm 5,2$ & $41,3 \pm 5,7$ & \\
\hline Tinggi badan $(\mathrm{cm} \pm \mathrm{SD})^{3}$ & $157,1 \pm 6,8$ & $156,8 \pm 8,4$ & \\
\hline IMT $\left(\mathrm{kg} / \mathrm{m}^{2} \pm \mathrm{SD}\right)^{1}$ & $16,9 \pm 1,4$ & $16,8 \pm 1,3$ & \\
\hline \multicolumn{4}{|l|}{ Kategori smear sputum (\%) ${ }^{4}$} \\
\hline+ & 39,2 & 26,9 & \\
\hline++ & 13,0 & 26,9 & \\
\hline \multirow[t]{2}{*}{+++} & 47,8 & 46,2 & \\
\hline & 100,0 & 100,0 & \\
\hline
\end{tabular}

${ }^{1}$ Independent t-test, $p>0,05 ;{ }^{2}$ Chi-squared test, $p>0,05 ;{ }^{3}$ Mann-Whitney $\mathrm{U}$ test, $p>0,05 ;{ }^{4}$ Chi-square test, $p>0,05$

\section{Koloni Mikroflora Feses}

\section{Bakteri probiotik Lactobacillus sp}

Pada Gambar 1, ditunjukkan dalam grafik bahwa keadaan populasi awal bakteri probiotik Lactobacillus sp di kedua kelompok (MSM dan MO) dalam keseimbangan cukup baik (rata-rata populasi 6,1-6,2 $\log _{10} \mathrm{cfu} / \mathrm{gr}$ feses). Perbedaan populasi Lactobacillus $s p$ diantara kedua kelompok tidak bermakna pada semua fase $(p>0,05)$. Selama pemberian obat anti TB (OAT) dan suplemen terjadi penurunan koloni total (within group, rata-rata penurunan sebesar 0,6-
$0,8 \log 10 \mathrm{cfu} / \mathrm{gr}$ feses di bulan yang bermakna $(p<0,05)$ tetapi di waktu yang berbeda yaitu di kelompok MSM (fase bulan 2) dan kelompok MO (fase bulan 1).

Penurunan populasi Lactobacillus sp pada kelompok MSM lebih lambat dibandingkan kelompok $\mathrm{MO}$, kemungkinan dari pengaruh pemberian suplemen probiotik eksogenus yang mampu mengganti mikroflora yang mati akibat tekanan penggunaan antibiotik obat anti tuberkulosis. Bakteri probiotik eksogenus memiliki mekanisme terapeutik substitusi terhadap bakteri indigenus, dengan cara 
melakukan penggantian bakteri indigenus pada lumen usus ${ }^{18}$. Hasil di atas juga sesuai dengan penelitian pemberian probiotik multispesies pada orang sehat yang diberi antibiotika amoxycillin selama 1 minggu, yaitu selama pemberian probiotik populasi Lactobacillus $s p$ dapat dipertahankan, sedangkan kelompok kontrol mengalami penurunan ${ }^{19}$. Lactobacillus $s p$ merupakan residen di daerah distal usus halus lebih besar mengalami tekanan antibiotik dibandingkan Bifidobacterium sp yang memiliki habitat hidup di daerah proximal hingga distal kolon
Namun demikian pemberian suplemen sinbiotik dan zat gizi mikro tidak mengakibatkan terjadinya perbedaan populasi bakteri probiotik diantara kedua kelompok $(p>0,05)$. Hal ini terjadi karena populasi kedua bakteri probiotik pada fase awal di kedua kelompok cukup tinggi (rata-rata > $6 \log _{10} \mathrm{cfu} / \mathrm{gr}$ feses). Data penelitian ini menunjukkan bahwa umumnya subjek masih memiliki keseimbangan mikroflora yang cukup baik (populasi Lactobcillus $s p \geq 3.0 \log _{10} \mathrm{cfu} / \mathrm{gr}$ feses) yaitu 70 subjek (92,3\%).

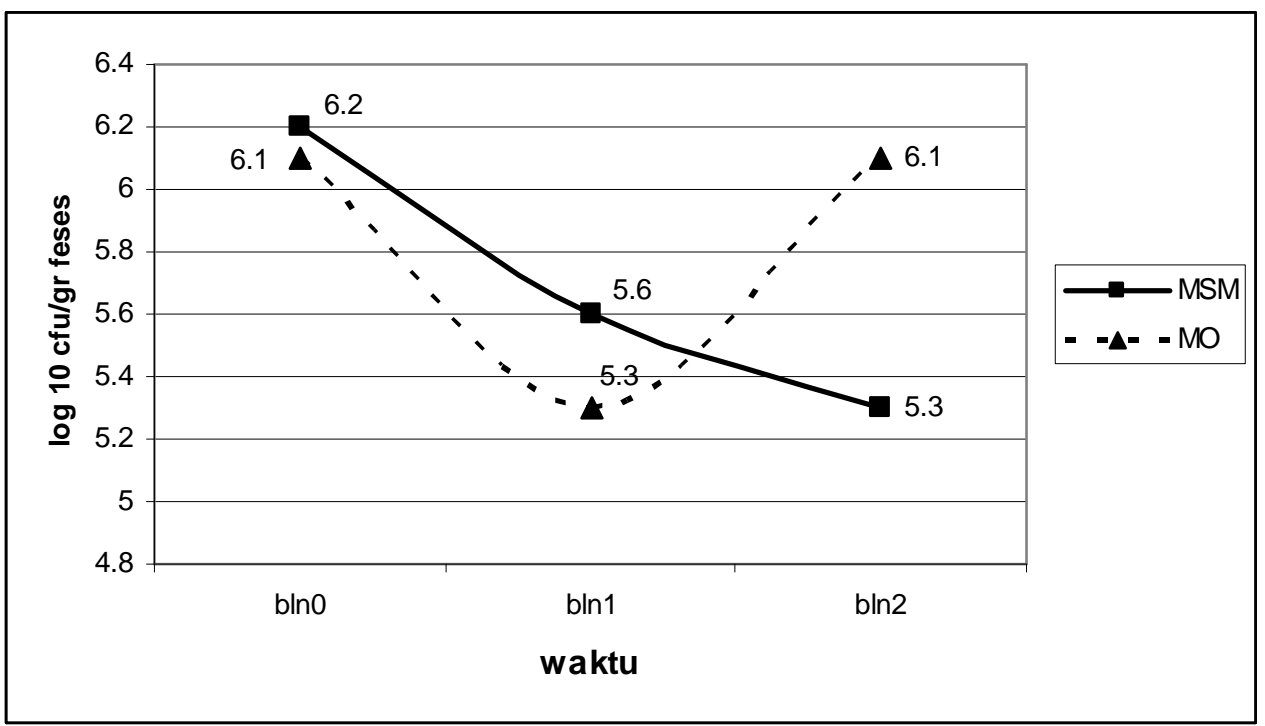

Kelompok MSM: penurunan populasi Lactobacillus sp bln $0-$ bln2, $p<0,05$

Kelompok MO: penurunan populasi Lactobacillus sp bln0 - bln 1, $p<0,05$

Gambar 1

Perubahan koloni bakteri Lactobacillus sp

\section{Bakteri probiotik Bifidobacterium sp}

Grafik pada Gambar 2, menunjukkan bahwa populasi bakteri probiotik Bifidobacterium sp di kedua kelompok (MSM dan MO) dalam keseimbangan yang baik (ratarata populasi 9,5-9,6 log ${ }_{10} \mathrm{cfu} / \mathrm{gr}$ feses). Terjadi kenaikan populasi Bifidobacterium sp (rata-rata $0,1 \log _{10}$ cfu/gram feses) di kedua kelompok di semua fase intervensi, meskipun tidak menunjukkan perbedaan bermakna $(p>0,05)$ baik diantara kelompok (between group) maupun dalam kelompok (within groups).

Meningkatnya populasi bakteri probiotik di kedua kelompok bisa diakibatkan berkurangnya tekanan antibiotika saat di habitat bakteri ini hidup yaitu di usus besar (kolon) dan suplai suplemen yang memiliki kapasitas bifidogenik.
Pemberian suplemen protein berbasis susu (kelompok MO) sama efektifnya dengan pemberian suplemen Bifidobacterium longum (kelompok MSM) dalam memperbaiki dan meningkatkan populasi mikroflora selama 2 bulan intervensi. Peningkatan populasi Bifidobacterium sp pada kelompok MO (tidak disuplai bakteri probiotik eksogenus), bisa terjadi karena suplemen protein berbasis susu mengandung unsur prebiotik (bifidogenik) yang dapat menunjang pertumbuhan bakteri probiotik. Komposisi suplemen protein berbasis susu mengandung sukrosa, laktosa, whey protein dan maltodextrin. Keempat bahan penyusun suplemen diatas memiliki sifat prebiotik yang menunjang pertumbuhan bakteri probiotik $^{20,21,22}$. Hasil ini sesuai dengan 
penelitian sebelumnya mengenai pengaruh pemberian prebiotik HP-Inulin terhadap kenaikan yang kecil populasi Bifidobacterium spp setelah 14 hari pemberian ${ }^{23}$.

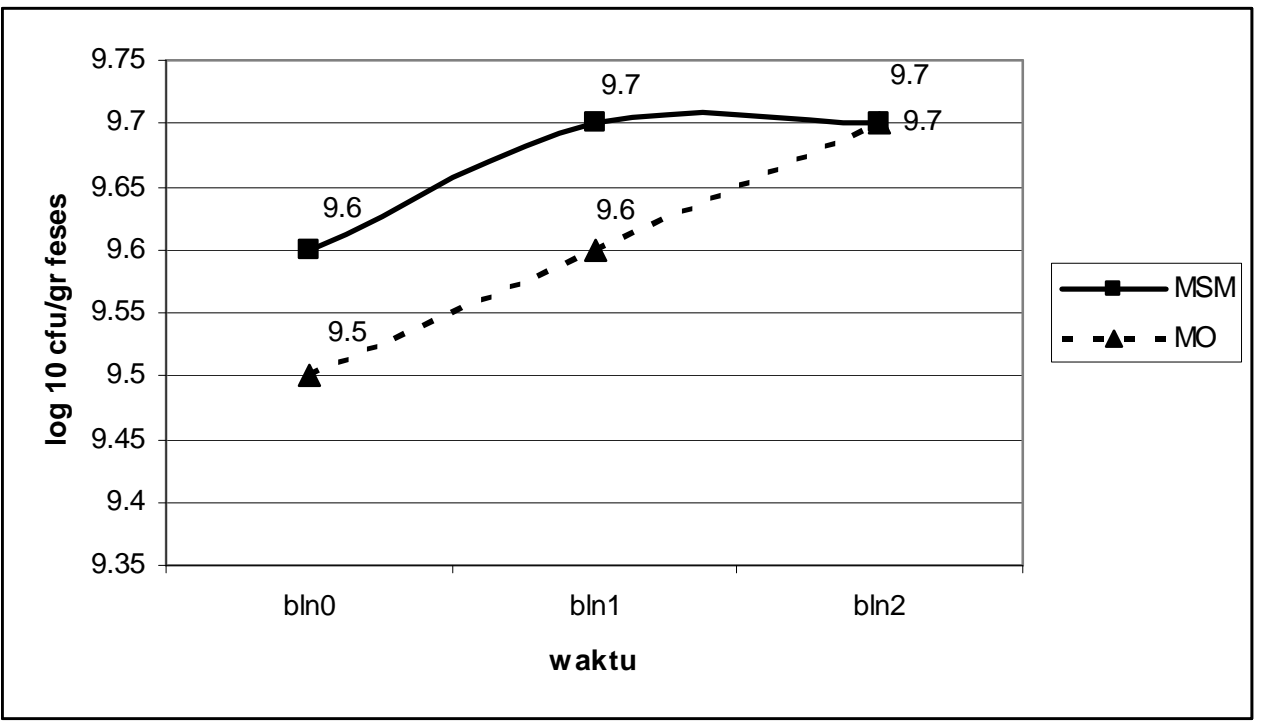

Gambar 2

Perubahan koloni bakteri Bifidobacterium sp

\section{Status gizi}

\section{Berat badan}

Pada Tabel 2, kedua kelompok MSM dan MO (within group) pada semua fase menunjukkan kenaikan berat badan yang nyata $(p<0,05)$, tetapi di antara kedua kelompok (between groups) tidak menunjukkan perbedaan $(p>0,05)$, hal ini menunjukkan bahwa tidak ada pengaruh langsung pemberian suplemen sinbiotik dan zat gizi mikro terhadap kenaikan berat badan, tetapi pemberian suplemen protein berbasis susu pada kedua kelompok cukup efektif meningkatkan berat badan. Rata-rata kenaikan berat badan subjek dalam 2 bulan pertama pada kelompok MSM sebesar 2,2 kg atau lebih rendah dari kelompok $\mathrm{MO}$ sebesar $3,4 \mathrm{~kg}$. Hasil kenaikan berat badan pada penelitian ini masih sebanding dengan hasil penelitian terdahulu pada kelompok TBC dengan KEK yang mendapatkan suplemen tinggi energi yaitu sebesar 2,6 kg dalam 6 minggu 4 atau sama dengan kenaikan berat badan sebesar 2,2 kg pada subjek TBC (gabungan KEK dan non KEK) yang menerima suplemen zat gizi mikro selama 2 bulan. ${ }^{24}$

\section{Indeks Masa Tubuh (IMT)}

Seperti halnya data berat badan, IMT meningkat setiap fasenya (Tabel 2), yaitu pada bulan 1 meningkat masing-masing sebesar 0,40,5 poin pada kelompok MSM dan MO, kemudian pada bulan 2 meningkat masingmasing kelompok menjadi sebesar 0,8 poin dan 1,0 poin. Pada Gambar 3, Kedua kelompok sama-sama berhasil menurunkan prevalensi KEK pada bulan pertama (sebesar 20,8\% kelompok MSM dan 26,9\% kelompok MO) dan bulan kedua (masing-masing menjadi sebesar $39,1 \%$ dan $31,8 \%$ ). Dibutuhkan kenaikan berat badan yang lebih besar untuk merubah keseimbangan energi positif dan menuntaskan penurunan prevalensi KEK.

Perubahan nilai indeks masa tubuh (IMT) di dalam kedua kelompok (within group) di seluruh fase menunjukkan kenaikan yang nyata $(p<0,01)$, tetapi tidak ada perbedaan nyata kenaikan IMT diantara kedua kelompok (between group) di semua fase $(p>0,05)$. Hal ini bisa terjadi karena dalam dua bulan pertama, subjek kedua kelompok sama-sama menggunakan suplemen dengan kandungan energi dan protein yang sama dan konsumsi harian yang tidak jauh berbeda. Hasil penelitian terdahulu pada kelompok yang serupa, menunjukkan asupan energi dari konsumsi normal harian tidak menunjukkan perbedaan antara kelompok intervensi dan kontrol dalam 6 minggu pertama ${ }^{3}$. 
Tabel 2

Perubahan Parameter Berat Badan, Indeks Massa Tubuh (IMT)

\begin{tabular}{|c|c|c|c|c|c|c|}
\hline \multirow{2}{*}{ Fase } & \multicolumn{2}{|c|}{ Kelompok MSM } & \multicolumn{2}{|c|}{ Kelompok MO } & \multicolumn{2}{|c|}{ Probabilitas $(p)$} \\
\hline & $\mathrm{BB}(\mathrm{Kg})$ & IMT & $\mathrm{BB}(\mathrm{Kg})$ & IMT & BB & IMT \\
\hline $\begin{array}{l}\text { Sebelum } \\
(\text { mean } \pm S D)\end{array}$ & $41,7 \pm 5.2$ & $16,9 \pm 1,4$ & $41,3 \pm 5,7$ & $16,8 \pm 1,3$ & $0,767^{d}$ & $0,967^{d}$ \\
\hline Sesudah 1 bulan & $43,1 \pm 6,0$ & $17,3 \pm 1,6$ & $43,0 \pm 6,3$ & $17,3 \pm 1,5$ & $\begin{array}{l}0,961 \mathrm{~d} ; 0,000^{f 1^{* *}} \\
0,000^{\mathrm{f} 2^{* *}}\end{array}$ & $\begin{array}{l}0,925^{d} ; 0,001+3^{* *} \\
0,013^{f 4^{*}}\end{array}$ \\
\hline Selisiha & $1,4 \pm 1,7$ & $0,4 \pm 0,6$ & $1,7 \pm 1,5$ & $0,5 \pm 0,8$ & $0,855^{d}$ & $0,445^{\mathrm{e}}$ \\
\hline Sesudah 2 bulan & $43,9 \pm 6,7$ & $17,7 \pm 1,6$ & $44,7 \pm 5,4$ & $17,8 \pm 1,2$ & $\begin{array}{l}0,671 \mathrm{~d} ; 0,000^{f 1^{* *}} \\
0,000^{; 2^{* *}}\end{array}$ & $\begin{array}{l}0,843^{\mathrm{d}} ; 0,001^{13^{* *}} \\
0,001^{14^{4 *}}\end{array}$ \\
\hline selisih ${ }^{b}$ & $2,2 \pm 2,4$ & $0,8 \pm 0,8$ & $3,4 \pm 1,8$ & $1,0 \pm 0,9$ & $0.874^{d}$ & $0,745^{d}$ \\
\hline
\end{tabular}

${ }^{a}$ selisih sebelum dan sesudah 1 bulan; ${ }^{d}$ idependent $t$-test; ${ }^{\mathrm{f} 2}$ Paired $t$-test kelompok MO

${ }^{b}$ selisih sebelum dan sesudah 2 bulan; e Mann-Whitney $U$ test; ${ }^{3}$ Wilcoxon Signed Ranks test kelompok MSM

${ }^{\mathrm{c}}$ selisih sebelum dan sesudah 6 bulan; ${ }^{\mathrm{f} 1}$ Paired $t$-test kelompok MSM; ${ }^{\mathrm{f} 4}$ Wilcoxon Signed Ranks test kelompok MO ;

berbeda nyata $p<0,05 ;{ }^{*}$ berbeda nyata $p<0,01$

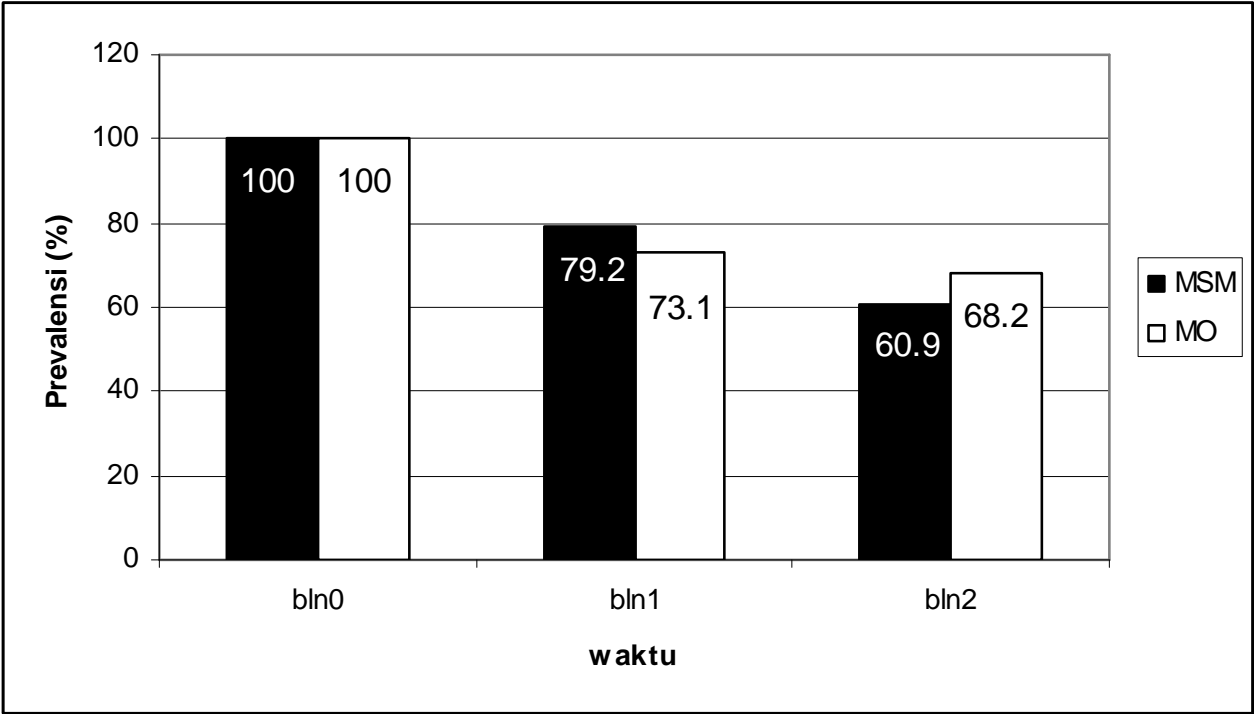

Gambar 3

Perubahan Prevalensi KEK Subjek Kelompok MSM dan MO

\section{Perubahan Lemak Tubuh}

Pada Tabel 3, persentase lemak tubuh diantara kedua kelompok (between group) di semua fase tidak menunjukkan perbedaan yang nyata $\quad(p>0,05)$. Sedangkan kenaikan persentase lemak tubuh menunjukkan perbedaan yang nyata $(p<0,05)$ pada subjek dalam masing-masing kelompok MSM dan MO (within group). Kenaikan lemak tubuh subjek laki-laki lebih tinggi dibandingkan subjek perempuan sebagai akibat dari kenaikan berat badan subjek laki-laki lebih besar dibandingkan subjek perempuan $(p<0,05)$.

Pada penderita TBC paru yang menjalani pengobatan, kenaikan berat badan berhubungan positif dengan persentase masa lemak tubuh, tetapi tidak berhubungan dengan masa protein ${ }^{11}$. Hal ini terjadi karena pada penderita TBC paru tidak terjadi perubahan nyata turn-over protein, karena asupan protein digunakan sebagian besar untuk menghasilkan energi (akibat sebelumnya keseimbangan energi negatif), sehingga fat deposit rate lebih 
besar daripada lean tissue deposit ${ }^{3}$. Pada penyakit infeksi kronis seperti TBC paru, terjadi perubahan laju metabolisme tubuh akibat terjadinya down-regulation ekspresi gen. Selama fase bulan ke 1 dan 2, asupan energi dan protein lebih utama digunakan untuk memperbaiki keseimbangan energi negatif (karena kenaikan berat badan yang masih kecil), sehingga prevalensi KEK di kedua kelompok masih cukup tinggi (Gambar 3). Padahal kenaikan IMT di bulan-bulan selanjutnya, akan diikuti dengan kenaikan lean mass dan fat mass ${ }^{3}$.
Kenaikan persentase lemak tubuh pada penderita TBC paru, merupakan indikator awal yang menandai terjadinya keseimbangan energi kearah keseimbangan energi positif. Sedangkan akselerasi penyembuhan penyakit TBC paru, memerlukan perbaikan pada indikator-indikator penting lainnya seperti menurunnya inflamasi, meningkatnya respon imun dan sintesis sel-sel imunitas sebagai akibat membaiknya ekspresi gen (transkripsi dan translasi). Perubahan positif pada indikator-indikator ini sangat ditentukan oleh keseimbangan protein tubuh.

Tabel 3

Perubahan Persentase Masa Lemak

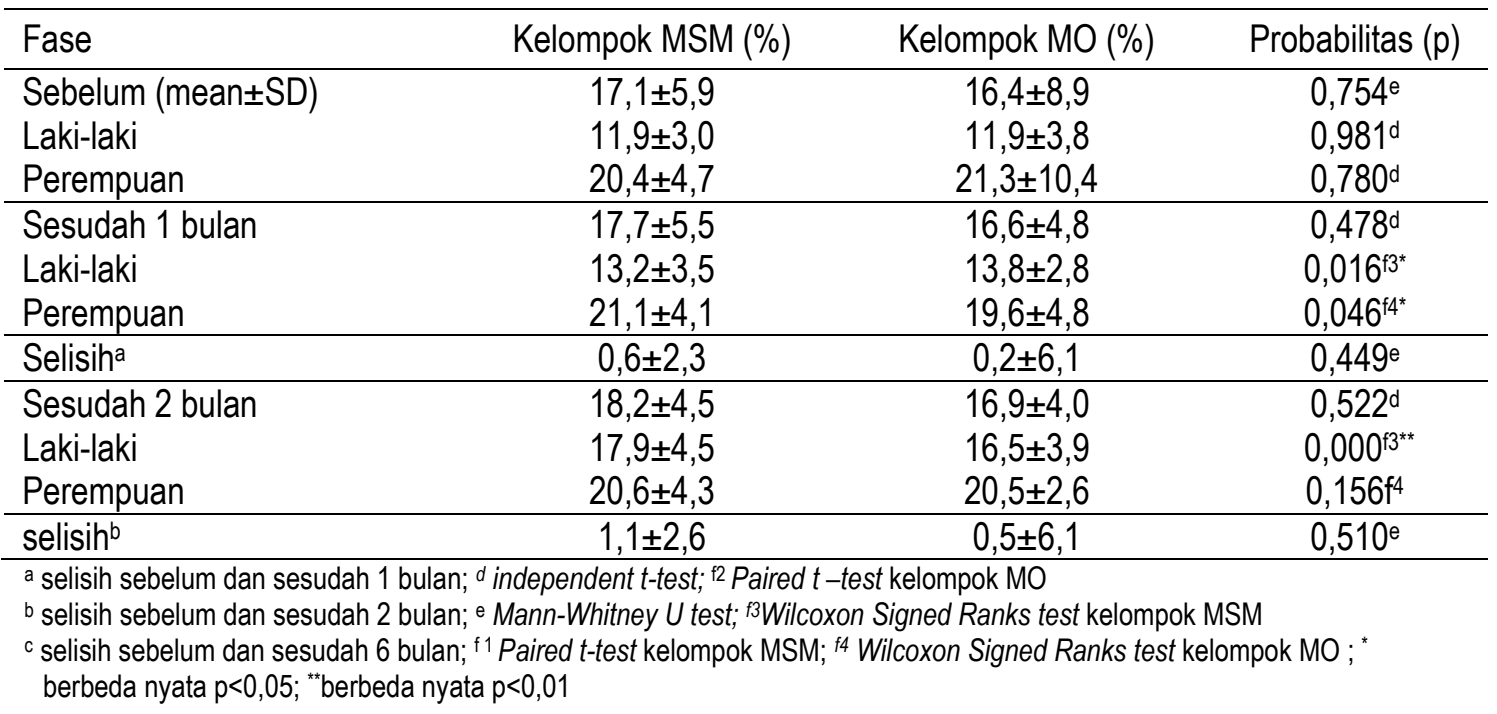

Tabel 4

Perubahan kadar hemoglobin

\begin{tabular}{|c|c|c|c|}
\hline Fase & $\begin{array}{c}\text { Kelompok MSM } \\
(\mathrm{mg} / \mathrm{dL})\end{array}$ & $\begin{array}{c}\text { Kelompok MO } \\
(\mathrm{mg} / \mathrm{dL})\end{array}$ & Probabilitas $(\mathrm{p})$ \\
\hline Sebelum (mean $\pm S D$ ) & $11,7 \pm 1,9$ & $11,0 \pm 2,0$ & $0,222^{d}$ \\
\hline Laki-laki & $12,4 \pm 1,3$ & $12,4 \pm 1,9$ & $0,990^{d}$ \\
\hline Perempuan & $11,8 \pm 1,9$ & $10,7 \pm 1,5$ & $0,065^{d}$ \\
\hline Sesudah 1 bulan & $12,1 \pm 1,4$ & $12,2 \pm 1,9$ & $0,844^{d}$ \\
\hline Laki-laki & $13,6 \pm 1,0$ & $13,5 \pm 1,6$ & $0,049^{f 1^{*}}$ \\
\hline Perempuan & $11,9 \pm 1,0$ & $11,2 \pm 1,4$ & $0,000^{f 2^{* *}}$ \\
\hline Selisiha & $0,4 \pm 1,5$ & $1,2 \pm 0,8$ & $0,109^{d}$ \\
\hline Sesudah 2 bulan & $12,7 \pm 1,4$ & $13,1 \pm 3,1$ & $0,607^{d}$ \\
\hline Laki-laki & $14,0 \pm 1,1$ & $14,1 \pm 1,6$ & $0,013^{f 1^{* *}}$ \\
\hline Perempuan & $12,3 \pm 1,1$ & $12,2 \pm 3,4$ & $0,000^{f 2^{* *}}$ \\
\hline selisih $^{b}$ & $1,0 \pm 1,5$ & $2,1 \pm 2,1$ & $0,146^{d}$ \\
\hline
\end{tabular}




\section{Hemoglobin}

Membaiknya kondisi kesehatan penderita TBC paru, ditandai dengan meningkatnya kadar hemoglobin. Pada Tabel 4, kenaikan hemoglobin di dalam kedua kelompok (within group) menunjukkan perbedaan yang nyata di semua fase $(p<0,05)$. Sedangkan kedua kelompok tidak menunjukkan perbedaan kadar hemoglobin (between groups) yang nyata $(p>0,05)$. Subjek laki-laki lebih cepat mengalami kenaikan kadar hemoglobin dibanding subjek perempuan di kedua kelompok (1,1-1,2 mg/dl dan 0,1-0,5 mg/dl di bulan 1). Hal ini menunjukkan bahwa subjek laki-laki, lebih cepat mengalami perbaikan metabolisme tubuh, sebagai akibat lebih cepatnya mengalami keseimbangan energi positif (kenaikan persentase lemak tubuh). Menurunnya tingkat inflamasi dan membaiknya napsu makan subjek, menjadi faktor menentukan kenaikan kadar hemoglobin.

\section{Serum Vitamin A dan Zinc}

Vitamin A dan zinc adalah zat gizi mikro berperan penting dalam fungsi sistem imunitas bawaan (Innate immunity) maupun perolehan (adaptive immunity) dan mempertahankan integritas sel mukosa (25), juga diperlukan dalam ekspresi gen di selular baik di level transkripsi maupun translasi (26). Untuk mobilisasi kedua zat gizi mikro memerlukan karier berupa protein transporter (retinol binding protein dan metallothionine atau albumin) untuk mengikat dan memindahkan ke jaringan target perifer (25). Pengukuran kadar vitamin A dan zinc di serum lebih mencerminkan status di level transport bukan di level fungsi (25), sehingga meskipun vitamin A dalam sirkulasi darah tinggi, tetapi apabila sintesis reseptor di sel rendah maka uptake juga rendah.

Tabel 5

Perubahan Kadar Vitamin A Serum dan Zinc Serum

\begin{tabular}{|c|c|c|c|c|c|c|}
\hline \multirow[b]{2}{*}{ Fase } & \multicolumn{2}{|c|}{ Kelompok MSM } & \multicolumn{2}{|c|}{ Kelompok MO } & \multicolumn{2}{|c|}{ Probabilitas (p) } \\
\hline & $\begin{array}{l}\text { Vitamin } A \\
\text { (umol/L) }\end{array}$ & $\begin{array}{c}\text { Zinc } \\
\text { (umol/L) }\end{array}$ & $\begin{array}{l}\text { Vitamin A } \\
\text { (umol/L) }\end{array}$ & $\begin{array}{c}\text { Zinc } \\
\text { (umol/L) }\end{array}$ & Vitamin A & Zinc \\
\hline Sebelum (mean $\pm S D$ ) & $0,9 \pm 0,5$ & $14,0 \pm 1,5$ & $1,0 \pm 0,5$ & $15,6 \pm 3,4$ & $0,695^{d}$ & $0,265^{d}$ \\
\hline Sesudah 1 bulan & $1,2 \pm 0,4$ & $12,5 \pm 1,2$ & $1,1 \pm 0,5$ & $15,1 \pm 3,0$ & $0,225^{\mathrm{d}} ; 0,024^{41^{*}} 0,061^{12^{*}}$ & $0,186^{\mathrm{d}} ; 0,057^{f 1} ; 0,174^{f 2}$ \\
\hline Selisiha & $0,3 \pm 0,6$ & $-1,8 \pm 1,9$ & $0,1 \pm 0,4$ & $-0,5 \pm 2,4$ & $0,460^{d}$ & $0,985^{d}$ \\
\hline Sesudah 2 bulan & $1,3 \pm 0,3$ & $13,3 \pm 2,7$ & $1,4 \pm 0,6$ & $14,7 \pm 2,1$ & $0,631^{d} ; 0,027^{f 1^{*}} ; 0,001^{12^{2 * *}}$ & $0,950^{\mathrm{d}} ; 0,772^{f 1} ; 0,019^{f 2^{*}}$ \\
\hline selisih $^{b}$ & $0,4 \pm 0,7$ & $-0,7 \pm 2,4$ & $0,4 \pm 0,4$ & $-0,9 \pm 2,1$ & $0,995^{d}$ & $0,135^{d}$ \\
\hline
\end{tabular}

Perubahan kadar vitamin A serum di kedua kelompok (MSM dan MO), menunjukkan kenaikan yang bermakna $(p<0,05)$, kelompok MSM mulai lebih awal yaitu pada bulan 1 sedangkan kelompok MO pada bulan 2. Namun pada bulan 2, kedua kelompok sama-sama menunjukkan kenaikan yang bermakna. Hasil ini (kenaikan 0,4 umol/mL) melampauai kenaikan penelitian terdahulu $(0,3 \mathrm{umol} / \mathrm{mL})$ pada subjek diberi zat gizi mikro yang sama ${ }^{24}$. Kenaikan kadar vitamin A serum diduga karena meningkatnya retinol binding protein sebagai akibat tersedianya suplai protein dari suplemen susu.
Berbeda dengan kadar zinc serum ternyata di kedua kelompok mengalami penurunan dalam bulan 2 pertama. Hasil ini sama dengan penelitian terdahulu, terjadi penurunan zinc plasma sebesar 0,3-0,9 umol/mL dalam dua bulan pertama ${ }^{24}$. Terjadinya penurunan kadar zinc serum bisa diakibatkan oleh (a) status zinc yang masih cukup baik, sehingga terjadi pengaturan penyerapan, (b) terjadinya kompetisi penyerapan dengan mineral lain dan (c) membaiknya metabolisme tubuh berakibat meningkatnya uptake zinc oleh sel-sel tubuh sekaligus zinc beredar dalam darah relatif menurun ${ }^{23}$. 
Penggunaan zinc yang meningkat di antaranya untuk sel pagosit macrofag dalam pertahanan tubuh, redistribusi zinc ke hati dan sumsum tulang belakang selama inflamasi dan efek ethambutol terjadinya kehilangan zinc melalui urin ${ }^{24}$.

\section{SIMPULAN DAN SARAN}

\section{Simpulan}

1. Pemberian suplemen susu, sinbiotik dan zat gizi mikro atau suplemen susu saja pada penderita TBC Paru yang mendapat OAT sama-sama mampu meningkatkan status gizi subjek (within group): berat badan, IMT, lemak tubuh, hemoglobin $(p<0,05)$, tetapi tidak terdapat perbedaan yang bermakna diantara kedua kelompok (between group).

2. Pemberian suplemen susu, sinbiotik dan zat gizi mikro mampu meningkatkan kadar vitamin $A$ serum yang bermakna di masingmasing kelompok (within group) $(p<0,05)$, walaupun tidak beda nyata diantara kedua kelompok (between group).

3. Terjadinya penurunan kadar zinc serum di kedua kelompok, kemungkinan akibat meningkatnya uptake zinc oleh sel-sel untuk sintesis.

\section{Saran}

Adanya pengaruh positif suplemen susu, sinbiotik dan zat gizi mikro atau suplemen susu saja terhadap status gizi penderita TBC paru, dapat digunakan sebagai komplemen dalam standar kemoterapi. Untuk mendapatkan hasil lebih kuat, perlu dilakukan penelitian dengan menambah kelompok kontrol tanpa protein berbasis susu .

\section{UCAPAN TERIMA KASIH}

Tim lapangan dr. Alit, dr. Pupu, Bu Erna, Gita, Nisa, Asri, Desi, Hilda dan Bu Aan. Petugas analisis laboratorium Pak Supartono, Bu Hana, Pak Ali dan Bu Asih. Mitra lain atas dukungan dalam pelaksanaan, dukungan Yayasan Danone Indonesia.

\section{RUJUKAN}

1. WHO. The Global Plan to Stop Tuberculosis: Guideline for social mobilization. WHO. Geneva. 2003.

2. Depkes R.I. Profil Kesehatan Nasional. Jakarta. 2006

3. Paton N.I., Chua Y.K., Earnest A and Chee C.B.E. Randomized controlled trial of nutritional supplementation in patients with newly diagnosed tuberculosis and wasting. Am J Clin Nutr. 2004.80:460-5.

4. Sahiratmadja E., Alisjahbana B., de Boer T., Adnan I., Maya A., Danusantoso $H_{\text {., }}$ Nelwan R. H. H., Marzuki S, van der Meer J. W. M., van Crevel R., van de Vosse E., and. Ottenhoff1 T. H. M. Dynamic Changes in Pro- and Anti-Inflammatory Cytokine Profiles and Gamma Interferon Receptor Signaling Integrity Correlate with Tuberculosis Disease Activity and Response to Curative Treatment. Infection and Immunity. 2007. 75(2): 820-829.

5. Karyadi E., West C.E., Schultink W., Nelwan R.H.H., Gross R., Amin Z., Dolmans W.M.V., Schlebusch H. and van der Meer J.W.M. A double-blind, placebocontrolled study of vitamin $A$ and zinc supplementation in persons with tuberculosis in Indonesia:effects on clinical response and nutritional status. Am J Clin Nutr. 2002. 75:720-7.

6. Verbon A, Juffermans NP, van Deventer SJ. Serum concentration of cytokines in patients with active tuberculosis and after treatment. Clin Exp Immunol. 1999.115: 110-3.

7. Juffermans NP, Verbon $A$, van Deventer SJ, van Deutekom H, Speelman $P$, van der Poll T. Tumor necrosis factor and interleukin- 1 inhibitors as marker of disease activity of tuberculosis. Am J Respir Crit Car Med 1998. 157:1328-31

8. Miller LG, Asch SM, Yu El, Knowles L, Gelberg L, Davidson P. A population-based survey of tuberculosis symptoms: how atypical are atypical presentations? Clin Infect Dis 2000;30:293-9.

9. Erickson K.L. and Hubbard E. Probiotic Immunomodulation in Health and Disease. The Journal of Nutrition. 2000. 130:403S- 
409S.Aleman M., Schierloch P., de la Barrera S., Musella R.M., Saab M.A., Baldini M., Abbate E., Sasiain M.C., 2004. Mycobacterium tuberculosis triggers apoptosis in peripheral neutrophil involving Toll-like receptors 2 and p38 mitogen protein kinase in tuberculosis patients. Infect. Immun. 72: 5150-5158.

10. Alisjahbana B. Tuberculosis in Indonesia: Host Response and Patients Care. Dissertation. Universiteit Nijmegen. The Netherlands. Dian Rakyat. 2007.

11. Schwenk A, Hodgson L, Wright A, Ward LC, Rayner CFJ, Grubnic S, Griffin GE dan Macallan DC. Nutrient partitioning during treatment of tuberculosis: gain in body weight fat mass but not in protein mass. Am J Clin Nutr. 2004;79: 1006-12.

12. Sanders M.E. Consideration for Use of Probiotic Bacteria to Modulate Human Health. The Journal of Nutrition. 2000.130:384S-390S.

13. Sullivan A. and Nord C.E. Probiotic in Human Infection. Journal of Antimicrobial Chemotherapy. 2002. 50: 625-627

14. Barza M, Giuliano M, Jacobus NV dan Gorbach SL. Effect of broad spectrum parenteral antibiotics on colonization resistance of intestinal microflora of human. Antimicrobial Agents and Chemotherapy. 1987. Vol. 31, No.5: 723-727.

15. Gill H.S. and Cross M.L. 2002. Nutrition and Immune Fuction: Probiotic and Immune Function. CAB International Oxon. UK.

16. Playne M.J., and Crittenden R.G. Prebiotics from Lactose, Sucrose, 2004.

17. Lemeshow S, Hosmer Jr, DW, Klar Janelle dan Lwanga SK. 1997. Besar Sampel Dalam Penelitian Kesehatan. Gajahmada University Press.

18. Goossens D, Jonkers D, Russel M, Stobberingh E, Van Den Bogaard and Stockbrugger $R$. The effect of Lactobacillus plantarum $299 \mathrm{v}$ on the bacterial composition and metabolic activity in faeces of healthy volunteers: a placebocontrolled study on the onset and duration of effects. Aliment Pharmacol Ther, 2003.18:495-505.
19. Koning CJM, Jonkers DMAE, Stobberingh EE, Mulder L, Rombouts FM and Stockbrugger RW. The Effect of a Multispecies Probiotic on the Intestinal Microbiota and Bowel Movement in Healthy Volunteers Taking the Antibiotic Amoxycillin. Am J Gastroenterol. 2007. 102:1-12.

20. Shah N.P. Probiotic Bacteria: Selective Enumeration and Survival in Dairy Foods. Journal of Dairy Science. 2000. Vol. 83, No. 4: 894-907.Starch, and Plant Polysaccharides: Bioprocesses and Bio technology for Functional Foods and Nutraceuticaals edited by Jean- Richard Neeser and J. Bruce German. Marcel Dekker Inc. New York.

21. Van der Muleun R., Avonts L., and De Vuyst. Short Fractions of Oligofructose are preferentially Metabolized by Bifidobacterium animalis DN-173 010 . Applied and Environmental Microbiology. 2004. April. 1923-1930.

22. Fastinger ND, Karr-Lilienthal LK, Spears JK, Swanson KS, Zinn KE, Nava GM, Ohkuma K, Kanabori S, Gordon DT and Fahey GC. A Novel Resistant Maltodextrin Alters Gastrointestinal Tolerance Factors, Fecal Characteristics, and Fecal Microbiota in Healthy Adult Humans. Journal of the American College of Nutrition, 2008. Vol. 27, No.2 : 356-366.

23. Tuohy K.M., Finlay R.K., Wynne A.G., and Gibson G.R. A Human Volunteer Study on the Prebiotic Effects of HP-Inulin Fecal Bacteria Enumerated Using Fluorescent In Situ Hybridisation (FISH). Anaerobe. 2001. 7:113-118.

24. Karyadi, E. 2001. Tuberculosis in Indonesia: nutrition, immune response and social aspects. Dissertation. Universiteit Nijmegen. The Netherlands.

25. Berdanier C.D. dan Zempleni J. Advanced Nutrition: Macronutriens, Micronutrients and Metabolism. Boca Raton: CRC Press. 2009; 309-339, 476-482.

26. Harland JI. Nutrition and Genetics, Mapping Individual Health. ILSI Europe. 2005 